Revista Brasileira de Meteorologia, v.27, n.2, 229 - 242, 2012

\title{
CHARACTERIZATION OF OZONE TRANSPORT AMONG METROPOLITAN REGIONS
}

\author{
CLÁUDIA BOIAN ${ }^{1}$ E MARIA DE FÁTIAM ANDRADE ${ }^{2}$ \\ ${ }^{1}$ Universidade Federal do ABC, Centro de Engenharia, Modelagem e Ciências Sociais Aplicadas (UFABC/ \\ CECS), Santo André, SP, Brasil \\ ${ }^{2}$ Universidade de São Paulo, Instituto de Astronomia, Geofísica e Ciências Atmosféricas, Departamento de \\ Ciências Atmosféricas (USP/IAG/DCA), São Paulo, SP, Brasil \\ claudia.boian@ufabc.edu.br, mftandra@model.iag.usp.br
}

Received June 2011 - Accepted November 2011

\begin{abstract}
The aim of this work is to determine the interaction in terms of ozone transport between two metropolitan regions of São Paulo State: The Metropolitan Region of Campinas (MRC) and Metropolitan Region of São Paulo (MRSP), with different characteristics and dimensions. In order to describe the interaction between both regions, 3-D Eulerian photochemical CIT model was used with a new approach for São Paulo regions since most previous studies deal with individual areas considering the contribution of other areas only as boundary conditions. The results from the photochemical simulations showed that the ozone concentration in the MRC is associated to local emissions and the transport of ozone and its precursors from the MRSP, demonstrating the significant impact of a megacity in its neighborhood and the importance of meteorological and topography conditions in the transport of air pollutants from the local source to distant regions.

Keywords: Tropospheric Ozone, Transport of Pollutants, Photochemical Model, Urban Pollution

RESUMO: CARACTERIZAÇÃO DO TRANSPORTE DE OZÔNIO ENTRE REGIÕES METROPOLITANAS

O objetivo deste trabalho é determinar a interação em termos de ozônio e seus precursores, entre duas regiões metropolitanas do Estado de São Paulo: A Região Metropolitana de Campinas (MRC) e a Região Metropolitana de São Paulo (RMSP), com diferentes características e dimensões. A fim de descrever a interação entre estas duas regiões, foi utilizado o modelo fotoquímico Euleriano 3-D CIT com uma nova abordagem para o tratamento de regiões metropolitanas em São Paulo, vez que a maioria dos estudos anteriores tratava-as como áreas individuais considerando a contribuição de outras áreas somente como condições de contorno.

Os resultados das simulações fotoquímicas mostraram que as concentrações de ozônio na MRC estão associadas às emissões locais e ao transporte de ozônio e precursores da RMSP, demonstrando o significante impacto da megacidade nas vizinhanças e a importância das condições meteorológicas e topográficas no transporte de poluentes das fontes locais para regiões distantes.

Palavras-Chave: Ozônio Troposférico, Transporte de Poluentes, Modelo Fotoquímico, Poluição Urbana
\end{abstract}

\section{INTRODUCTION}

Megacities and other major urbanized centers (as metropolitan regions) represent large, concentrated sources of anthropogenic pollutants to the atmosphere, with consequences for both local air quality and for regional and global atmospheric chemistry. The tradeoffs between the regional buildups of pollutants and their sources versus long-range export due to meteorological characteristics vary as function of geographical location and season. Both horizontal and vertical transports contribute to pollutant export, and the overall degree of export is strongly governed by the lifetimes of pollutants (Lawrence et al., 2007). The most common air pollutants in urban environments are sulfur dioxide $\left(\mathrm{SO}_{2}\right)$, nitrogen oxides $\left(\mathrm{NO}, \mathrm{NO}_{2}\right)$, carbon monoxide $(\mathrm{CO})$, ozone $\left(\mathrm{O}_{3}\right)$ and suspended particulate matter. Oxides of nitrogen and sulfur in the urban plume can contribute 
to acid deposition at great distances from the city. Ozone concentrations are often elevated downwind of urban areas associated to the time lag involved in photochemical processes and NO scavenging in polluted atmospheres (Mage et al., 1996).

Ozone air pollution in megacities and metropolitan regions and the effects of their transport and precursors for distant areas from the source have been extensively studied including studies for the MRSP - Metropolitan Area of São Paulo (Molina and Molina, 2004); (Massambani and Andrade, 1994); (Andrade et al, 2004); (Lam et al., 2005); (AlvimFerraz et al., 2006) and this knowledge is very important in forecasting air quality. An important tool (recommended by the local environmental protection agencies) to simulate the air pollution dynamics for ozone is the use of photochemical air quality model which contains representations of emissions ratios, meteorological and photochemistry processes.

In urban areas tropospheric ozone is basically formed through chemical reactions between $\mathrm{NO}_{\mathrm{x}}$ and volatile organic compounds (VOC's) in the presence of sunlight. Emissions from motor vehicle exhaust, gasoline vapors, chemical solvents and industries are the major sources of VOC's (Lei et al, 2007).

The most important metropolitan regions in São Paulo State, Brazil, are the Metropolitan Region of São Paulo (MRSP) and Metropolitan Region of Campinas (MRC). The MRSP is considered a megacity with 19 million inhabitants in an area of $8511 \mathrm{~km}^{2}$, with important air pollution problems. The MRC has an area of approximately $3348 \mathrm{~km}^{2}$, about 2.3 million inhabitants and the major city of the region is Campinas

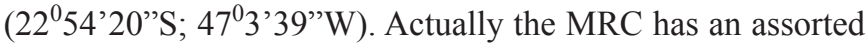
industrial park, a petrochemical complex in Paulinia city (far from Campinas $18 \mathrm{~km}$ ) and an important road system. According to the official air quality records from CETESB (São Paulo State Environmental Protection Agency), that has been monitoring ozone levels in MRC, the tropospheric ozone concentrations routinely exceed the $80 \mathrm{ppb}$ (parts per billion) hourly (Brazilian National Ambient Air-Quality Standard). In the years 2003 and 2004; for example, there were 39 and 30 times occurrences of violations of the standards, respectively. Some events of high ozone concentrations levels are associated to the prevailing wind from south-southeast direction. The MRSP is located 96 $\mathrm{km}$ southeast of this region and has routinely exceeded the air quality standards for ozone and PM10 (the Brazilian National ambient air-quality standard for PM10 is $50 \mu \mathrm{g} / \mathrm{m}^{3}$ annual mean or $150 \mu \mathrm{g} / \mathrm{m}^{3} 24 \mathrm{~h}$ average).

In the MRSP several studies have been performed to analyze the impacts of ozone precursors and meteorological conditions in surface ozone concentrations and air quality (Sanchez-Ccoyllo and Andrade, 2002); (Andrade et al., 2004); (Sanchez-Ccoyllo et al., 2006); (Martins et al., 2006a). For the MRC there are few studies for ozone air pollution (Tresmondi and Tomaz, 2004).
Martins et al. (2006b) studied the impact of emissions of biogenic volatile organic compounds (BVOCs) on formation of ozone $\left(\mathrm{O}_{3}\right)$ in the Metropolitan Region of São Paulo (MRSP) using the California Institute of Technology (CIT) photochemical model. In order to estimate the concentration of the most important compounds emitted by vegetation, environmental BVOCs were measured. Simulations of atmospheric $\mathrm{O}_{3}$ formation were carried out from August 9 to August 12, 1999 in order to calibrate the model and from August 22 to August 24, 2000 to verify the quality of the simulations. Simulations either included or excluded biogenic emissions. Comparing the results of simulations including biogenic emissions with those from simulations excluding such emissions revealed that biogenic emissions contributed to the formation of, on average, $15.3 \%$ higher $\mathrm{O}_{3}$ concentrations, $20.4 \%$ higher peroxyacetyl nitrate (PAN) concentrations, $1.7 \%$ higher nitrogen dioxide $\left(\mathrm{NO}_{2}\right)$ concentrations and $2.4 \%$ lower nitric oxide (NO) concentrations for first period. In second period of simulation similar behaviour was observed, but with smaller contribution than in the first period.

The aim of this work is to determine the interaction between these metropolitan regions concerning the evolution of ozone concentration. In order to describe the interaction between both regions, the 3-D Eulerian photochemical CIT model has been used to simulate the air pollution dynamics for ozone in the MRC and in the MRSP. This is the first study of the tropospheric ozone pollution for MRC using photochemical model to simulate the air pollution dynamics for ozone and to determine the interaction between the most important metropolian regions in São Paulo State, Brazil (MRSP and MRC). For this first approached it was considered only the emissions from mobile sources.

\section{CHARACTERIZATION OF STUDY AREA}

According to what was said previously the most important metropolitan regions in São Paulo State, Brazil, are the MRSP and MRC. The MRSP is a highly industrialized area of South America and its automotive fleet now exceeds 7.8 million vehicles and is the main source of air pollutant emissions (Sanchez-Ccoyllo et al, 2006). The MRC is a region undertaken large socio-economic development, it is implies in a fast population growing (for example, Campinas, the major city of the region, has nowadays more than one million inhabitants) and industrial activities with consequently a significant impact in the air quality of the region. As well as MRSP region, the MRC has also a significant automotive fleet. Table 1 shows the emission inventory for the Metropolitan Areas of São Paulo and Campinas (CETESB, 2003). It is possible to note the high industrial emissions of $\mathrm{HC}, \mathrm{NO}_{\mathrm{x}}$ and $\mathrm{SO}_{\mathrm{x}}$ in $\mathrm{MRC}$ (it is similar 
to MRSP emissions). The industrial activity in MRC represents $17 \%$ of total production in São Paulo State (CETESB, 2003).

From the climatological point of view MRC presents an average temperature between $18^{0}$ and $22^{\circ} \mathrm{C}$ from May to September and between $22^{\circ} \mathrm{C}$ and $24^{\circ} \mathrm{C}$ from October to April. The annual average precipitation is around $1470 \mathrm{~mm}$ and $80 \%$ of this occurs from October to March. The typical behavior of wind direction in the MRC region during the day is: (a) in early morning and evening the predominant wind directions are SSE and SE; (b) in morning the predominat wind direction is SSE, SE and NE and (c) in the afternoon the NNE, SSE, N, SSW and S are the most frequent directions. Then prevalence winds are between east and south (CETESB, 2004; Tresmondi and Tomaz, 2004). As in the MRSP, during the dry season, the minimum relative humidity can be around $15 \%$, mainly in September.

The localization of the main cities in the Metropolitan areas, São Paulo (SP), Campinas (CA), Paulinia (PA) and Americana (AM) is showed in the Figure 1a. Figure $1 \mathrm{~b}$ presents the topographic profile from São Paulo to MRC (Campinas; Paulinia; Americana). There is a decrease of $200 \mathrm{~m}$ from São Paulo to Americana. It occurs because among MRSP and MRC there is a transition region from plateau to depression, respectively. This kind of topography associated with prevalent wind direction from south and southeast favors the transport and accumulation of pollutants in the MRC.

\section{METHODOLOGY}

\subsection{Photochemical model description}

In this study it was used the 3-D Eulerian photochemical CIT model to simulate the air pollution dynamics for ozone in the MRC and in the MRSP, which is a photochemical model developed jointly by the California Institute of Technology and
Carnegie Mellon University, see McRae and Senfeild (1982; 1983); Russel et al. (1988); Harley et al (1993); Ulke and Andrade (2001); Sánchez-Ccoyllo et al. (2006).

The model consists of three basic modules (chemistry mechanism, meteorology and emissions), which simulates, respectively, dispersion in the planetary boundary layer, chemistry and emission inventories, including spatial and temporal distribution. The CIT airshed model is based on the numerical solution of the atmospheric diffusion equation. The input data for the model used to solve the atmospheric diffusion equation are the meteorological variables (temperature, absolute humidity, solar and ultraviolet radiation, mixing-layer height and three-dimensional wind fields), topographical characteristics (including surface roughness), and the rate of emission of the chemical species, and air-quality data for initial and boundary conditions, Martins et al. (2006a).

The model employs the 1999 California Statewide Air Pollution Research Center (SAPRC99) photochemical mechanism developed by Carter (2000a, b). The species used to represent the organic emissions were: acetone; alkane group 1; alkane group 2; alkane group 3; aromatics 1; aromatics 2; aromatic aldehydes; butadiene; benzene; acetaldehyde; ethanol; formaldehyde; isoprene; ketones; methanol; olephines 1 ; olephines 2 and remaining $\mathrm{C} 3+$ aldehydes. The species in SAPRC99 are grouped by reactivity of the compounds, as described by Sánchez-Ccoyllo et al. (2006).

\subsection{Model domain}

The simulations were performed for a $60 \mathrm{x} 40$ horizontal grid with $5 \mathrm{~km} \times 5 \mathrm{~km}$ resolution. The western corner of the area considered in the simulation is $24^{\circ} \mathrm{S} 48,1^{\circ} \mathrm{W}$, covering an area of $300 \mathrm{~km}$ east-west and $200 \mathrm{~km}$ south-north. This photochemical model uses the UTM coordinates (Universal Transverse Mercator).

Table 1 - Emission inventory for the Metropolitan Areas of São Paulo and Campinas (CETESB, 2003).

\begin{tabular}{|c|c|c|c|c|c|c|}
\hline \multirow{2}{*}{$\begin{array}{c}\text { Emissions } \\
\text { Sources }\end{array}$} & Metropolitan & \multicolumn{5}{|c|}{ Emission (1000 ton/year) } \\
\cline { 3 - 7 } & Region & $\mathrm{CO}$ & $\mathrm{HC}$ & $\mathrm{NO}_{\mathrm{x}}$ & $\mathrm{SO}_{\mathrm{x}}$ & $\mathrm{MP}$ \\
\hline \multirow{2}{*}{$\begin{array}{c}\text { Vehicle } \\
\text { (gasoline) }\end{array}$} & $\mathbf{M R S P}$ & $\mathbf{8 1 8 . 6 0}$ & $\mathbf{2 3 4 . 0 0}$ & $\mathbf{4 6 . 7 0}$ & $\mathbf{8 . 0 0}$ & $\mathbf{5 . 3 0}$ \\
\cline { 2 - 7 } & $\mathrm{MRC}$ & 117.32 & 33.30 & 6.700 & 1.15 & 0.77 \\
\hline \multirow{2}{*}{$\begin{array}{c}\text { Vehicle } \\
\text { (alcohol) }\end{array}$} & $\mathbf{M R S P}$ & $\mathbf{2 1 7 . 9}$ & $\mathbf{4 1 . 0}$ & $\mathbf{1 3 . 1}$ & - & - \\
\cline { 2 - 7 } & $\mathrm{MRC}$ & 34.55 & 6.50 & 2.07 & - & - \\
\hline \multirow{2}{*}{$\begin{array}{c}\text { Vehicle } \\
\text { (diesel) }\end{array}$} & MRSP & $\mathbf{4 5 3 . 6}$ & $\mathbf{7 4 . 3 0}$ & $\mathbf{3 3 3 . 2 0}$ & $\mathbf{1 1 . 5 0}$ & $\mathbf{2 0 . 3 0}$ \\
\cline { 2 - 7 } & $\mathrm{MRC}$ & 82.70 & 13.47 & 60.40 & 1.93 & 3.76 \\
\hline \multirow{2}{\text{Industrial}}{} & MRSP & $\mathbf{3 8 . 6}$ & $\mathbf{1 2 . 0 0}$ & $\mathbf{1 4 . 0 0}$ & $\mathbf{1 7 . 1 0}$ & $\mathbf{3 1 . 6 0}$ \\
\cline { 2 - 7 } & MRC & 0.5 & 11.82 & 17.79 & 25.15 & 5.62 \\
\hline
\end{tabular}




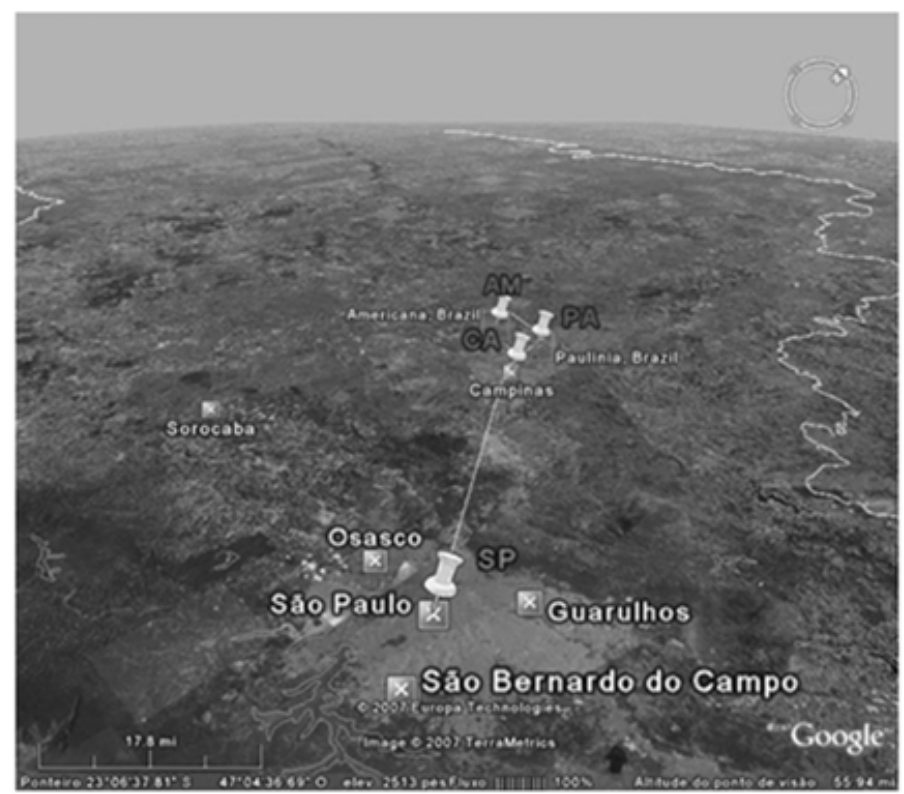

(a)

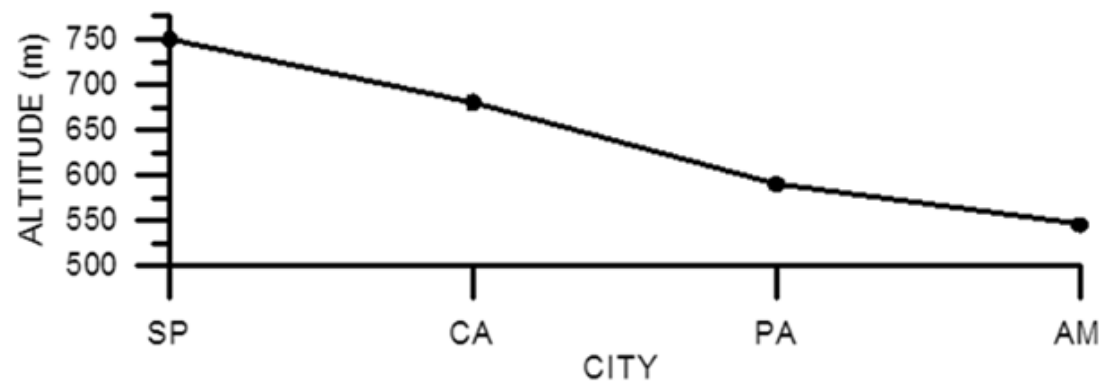

(b)

Figura 1 - (a) Satellite image showing the localization of the cities: São Paulo - SP (46.6W; 23.5S); Campinas - CA (47W; 22.9S), Paulinia - PA (47.2W; 22.8S) and Americana - AM (47.3W; 22.7S). (b) Topographic profile for São Paulo (SP), Campinas (CA), Paulinia (PA) and Americana (AM) cities.

As said previously the model is based on the numerical solution of the atmospheric diffusion equation in the planetary boundary layer. The vertical resolution of the model has five levels (1-5 levels, see Table 2) to represent all the boundary layer and the top of the model for these simulations is $1559 \mathrm{~m}$. The top of the model was determined with basis in the Doppler SODAR surface meteorological measurements of mixing-layer height.

\subsection{Air quality, meteorology, land use and topography data}

The air quality data are necessary for initial and contours conditions and also to evaluate the results of the model. The air quality and meteorological input parameters were obtained from CETESB (São Paulo Environmental Protection Agency) surface data measurements and they were interpolated for all grid cell according to the method described by Goodin et al. (1979).

The land use and topography data were obtained from the Brazilian Regional Atmospheric Modeling/Regional Atmospheric Modeling System BRAMS/RAMS (CPTEC, 2003, Freitas et al., 2005).

\subsection{Emissions}

The official emission inventory for $\mathrm{CO}, \mathrm{NO}_{\mathrm{x}}, \mathrm{SO}_{2}$ and total hydrocarbons was obtained from CETESB data. The total mass of pollutants emission is presented in Table 1. The hydrocarbons speciation is based on ambient and road tunnel measurements and lumped according to the classification of SAPRC chemical mechanism. These inventories were spatially and temporally distributed throughout the study 
Table 2 - Specifications of the vertical layers of the model: thickness and height of the top (m).

\begin{tabular}{cccc}
\hline Layer & Fraction & Thickness & Top \\
\hline 1 & 0,035 & 54.0 & 54 \\
2 & 0,105 & 163.7 & 218 \\
3 & 0,140 & 218.3 & 436 \\
4 & 0,330 & 514.5 & 951 \\
5 & 0,390 & 608.0 & 1559 \\
\hline
\end{tabular}

area and adjusted by a factor of 1.0 for $\mathrm{CO}, \mathrm{SO}_{2}$, by a factor of 1.2 for hydrocarbons and by a factor of 0.5 for $\mathrm{NO}_{\mathrm{x}}$ based on the analysis of ambient ratio measurements of $\mathrm{CO}, \mathrm{NO}$ and hydrocarbons made by CETESB (2003) and previous photochemical modeling studies for Sao Paulo (Andrade et al., 2004; Vivanco and Andrade, 2006). These adjustments are necessary because the emission inventory for the study area seems to be significantly overestimated for $\mathrm{NO}_{\mathrm{x}}$ and slightly underestimated for hydrocarbons, see Vivanco and Andrade (2006).

The spatial distribution of emissions in the grid cell was made proportionally of the number of vehicles for each city of MRSP and MRC, with data from DETRAN (2003). It was adopted a different temporal distribution for light (gasohol and alcohol) and diesel vehicles according to previous studied of factor of emission during the traffic jams and rush hour (Martins et al., 2006a).

\subsection{Initial and boundary condition}

Initial and boundary condition inputs, as well as $\mathrm{O}_{3}, \mathrm{CO}$, $\mathrm{NO}_{\mathrm{x}}$, and $\mathrm{SO}_{2}$ concentrations were obtained from CETESB airquality measurements taken at automatic stations. The hourly data were spatially interpolated and used as initial condition for $\mathrm{O}_{3}, \mathrm{CO}, \mathrm{NO}_{\mathrm{x}}$, and $\mathrm{SO}_{2}$. Boundary conditions were based on measurements and literature information, being the model very sensitive to them (Ulke and Andrade, 2001, Martins et al., 2006a).

\section{METEOROLOGICAL AND AIR QUALITY CONDITIONS DURING THE PERIOD OF SIMULATION}

The period considered for analysis was from September 30 to October 5, 2003. This period was very well documented and occorred high concentrations of ozone in both studied areas.

\subsection{Wind direction and velocity}

Some meteorological conditions were choosen to characterized the period of simulation in order to guarantee the existence of favorable conditions for ozone formation and possible events of air pollution transport from MRSP to MRC: (a) absent of precipitation and frontal systems in the area of simulation; (b) occurrence of high temperatures in MRC (c) main wind direction from south and southeast. According to these conditions the period from September 30, 2003 to October 5, 2003 was chosen for simulation with photochemical model CIT.

Figures $2 \mathrm{a}-2 \mathrm{~d}$ shows the Wind-Rose (wind direction and speed) for Paulinia from September 30, 2003 to October 5,2003 , divided in four periods of day: early morning (1-6 am); morning (7am-12 pm); afternoon (1-6 pm) and evening (7pm-12 am). It was observed for this period similar behavior to that found during the year (prevailing wind from southsoutheast direction): (a) early morning and evening S and SE; (b) morning mainly direction $\mathrm{SE}$ and $\mathrm{NO}$; (c) afternoon S, SE, $\mathrm{SO}$ and NO. It is important to observe that in the early morning and evening the wind direction is totally from $\mathrm{S}$ and $\mathrm{SE}$ and in the evening the wind speed is higher than other periods of day. These conditions are very important to maintain the transport of ozone and precursors from MRSP to MRC all the periods of day.

\subsection{Hourly ozone concentrations, temperature and humidity measured in Paulinia}

Figures 3, 4, 5a and 5b show the hourly ozone concentrations, temperature and humidity measured by CETESB in Paulinia from September 30, 2003 to October 5,2003 . With a typical diurnal variation, as expected, ozone concentrations reach a maximum during the day and a minimum during the night. During the day higher ozone concentrations were measured associated with higher temperature and lower humidity. At night and early morning with the absence of sunlight, a thermal inversion is often produced near the ground, which contributes to the deposition/chemical loss of ozone due to $\mathrm{NO}_{\mathrm{x}}$ consumption reactions, leading to the decrease of ozone concentrations. An example of this typical behavior is showed in Figures $3 \mathrm{a}$ and $5 \mathrm{a}$.

The lowest ozone concentrations were measured on September 30 . The day before was characterized by a passage of a frontal system over the region cleaning the air and minimizing the effects of transport.

A non expected event was observed during this period: in the majority of days it was measured peaks of ozone concentrations at night (around 10:00 pm, LT), see Figures 3b, $4 \mathrm{a}, 4 \mathrm{~b}$ and $5 \mathrm{~b}$. This can be classified as an evidence of transport processes of ozone and precursors. 


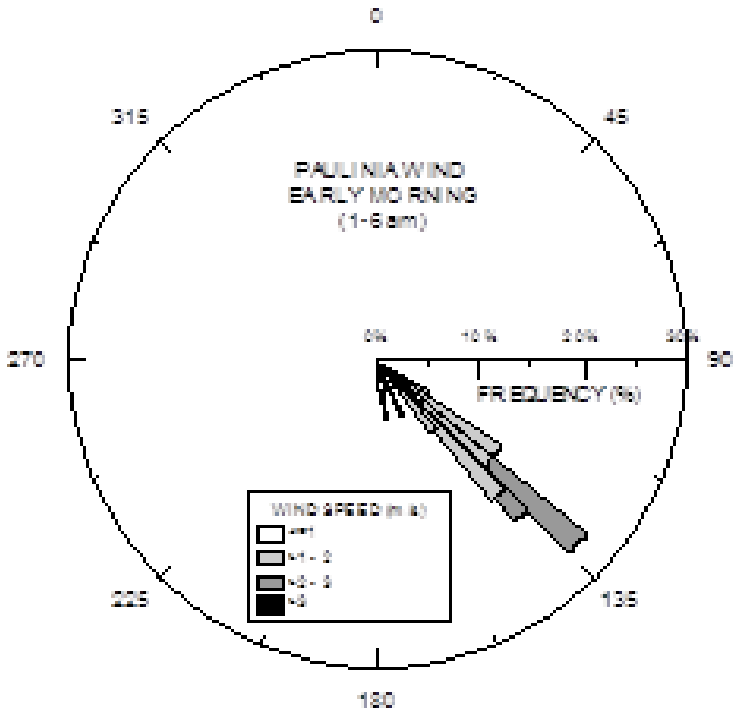

(a)

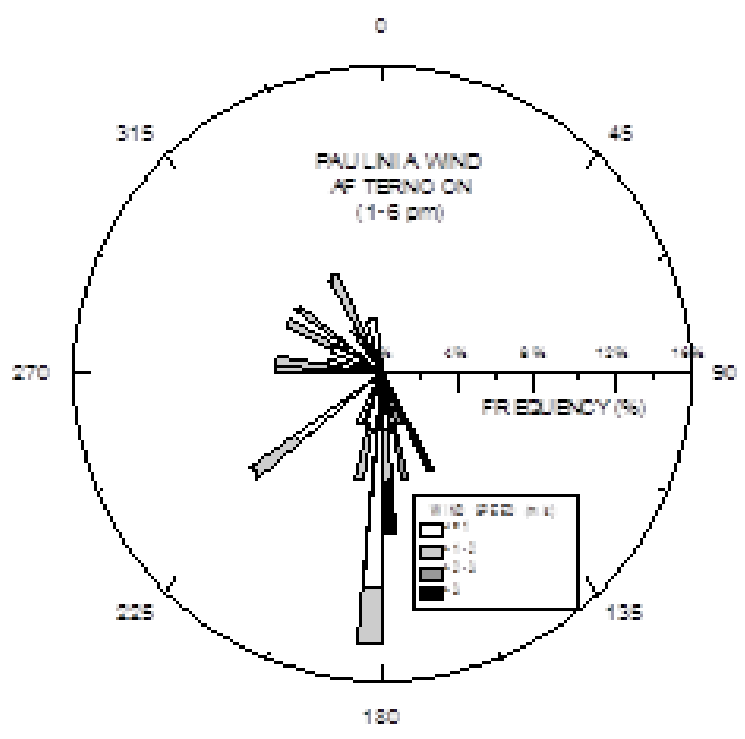

(c)

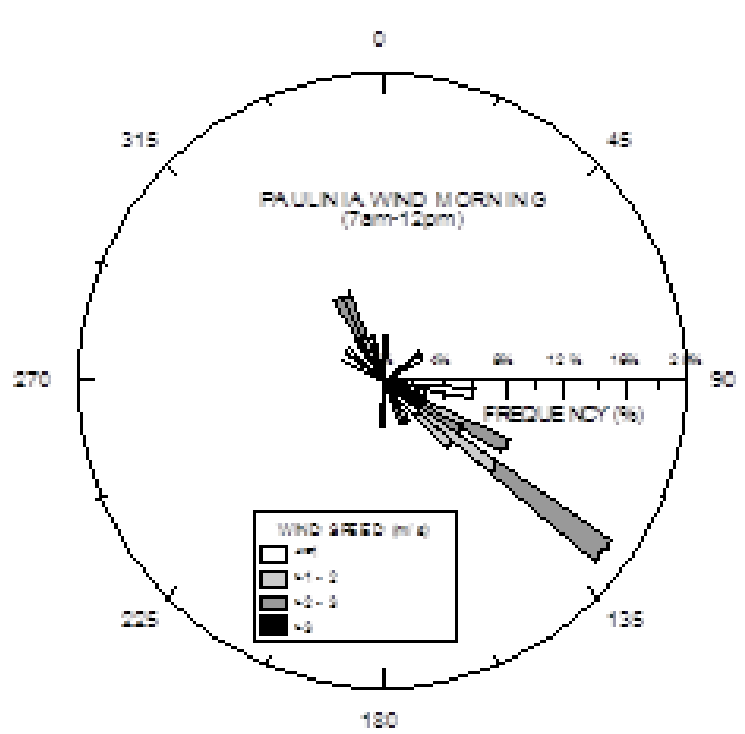

(b)

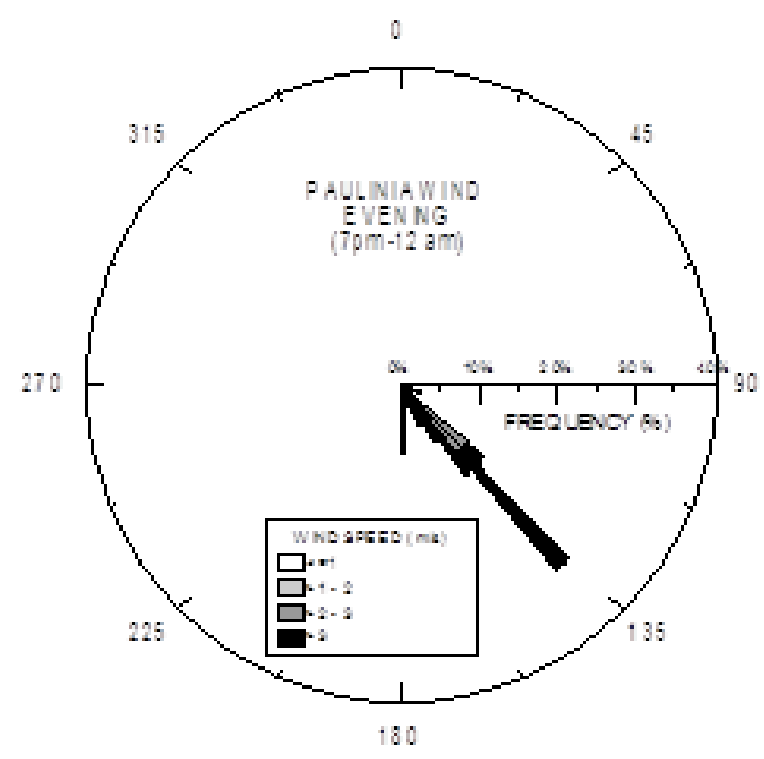

(d)

Figura 2 - Wind Rose for Paulinia from September 30, 2003 to October 5, 2003 divided in four period: (a) Early Morning (1- 6 am); (b) Morning (7am-12 pm); (c) Afternoon (1- 6 pm); (d) Evening (7pm-12 am).

The highest ozone concentrations (80-106 ppb) were measured on October 3, 2003; see Figure 4b. All theses aspects observed in ozone measurements were compared with the results of simulations.

\section{RESULTS}

\subsection{Comparisons between ozone concentrations measured and simulated for MRSP and Paulinia station (MRC)}

Figures 6 and 7 show a comparison between hourly ozone concentrations measured and simulated in MRSP and Paulinia Station (MRC), respectively, from September 30, 2003 to October 5, 2003. The ozone surface measurements were obtained by CETESB air quality monitoring stations and the simulated ozone concentrations were obtained from photochemical model CIT. For the MRSP s the simulated ozone concentrations at first level of model were compared with ozone measured at two stations (one located in a relatively clean area and other in a polluted region). For the MRC there is only one 
(a)

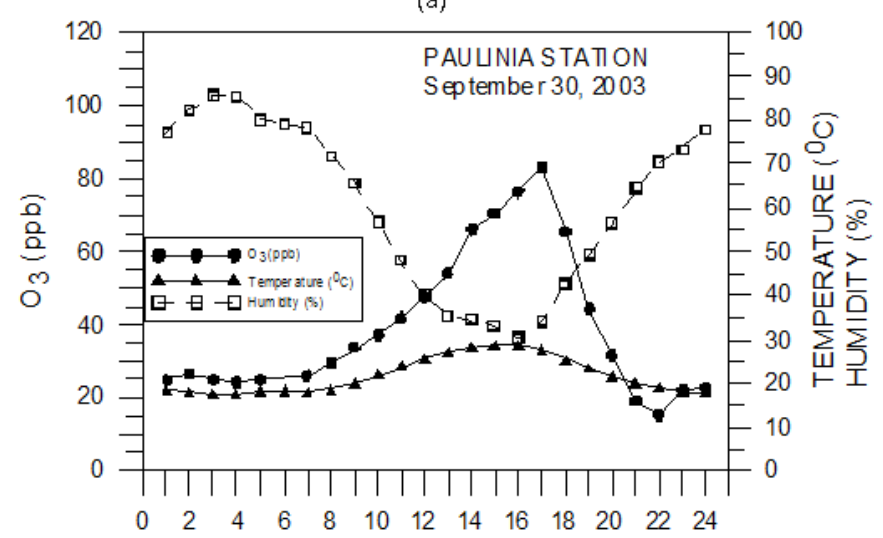

(b)

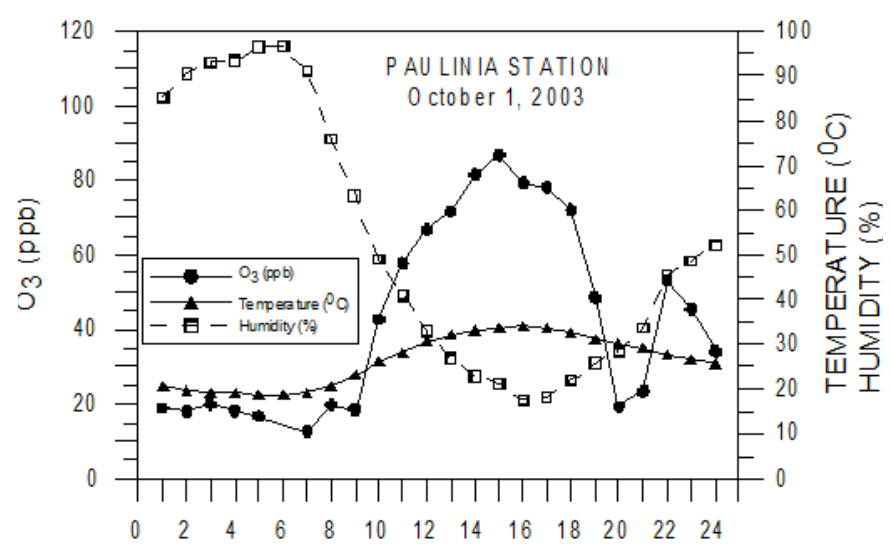

Figura 3 - Hourly ozone concentrations (in ppb), temperature (in $0 \mathrm{C}$ ) and humidity (in \%) measured by CETESB in Paulinia from September 30, 2003 to October 1, 2003 (a, b), respectively.

station of ozone surface measurements located in Paulinia city (Paulinia city is $18 \mathrm{~km}$ far from Campinas). It was observed better agreement in the peaks phase between concentrations measured and simulated in the MRSP. The highest ozone concentrations were measured on October 3, 2003 for both regions: MRSP and MRC.

\subsection{Results of photochemical simulation using CIT model}

\subsubsection{Ozone simulations on October 3, 2003}

The highest ozone concentrations in both regions: MRSP and MRC, during the period of simulation, were measured on October 3, 2003. To analyze the effects of ozone transport from MRSP to MRC two sceneries of sources emission were considered for simulations: (a) all the vehicular emissions from MRSP and MRC (b) only MRC vehicular emission. The first scenery describes the effects of local production and transport in the MRC with the influence of the MRSP and the second (a)

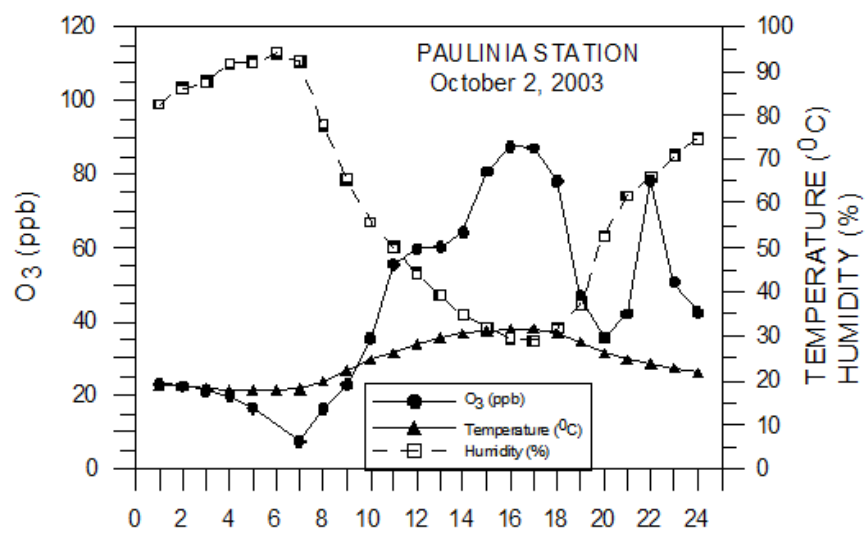

(b)

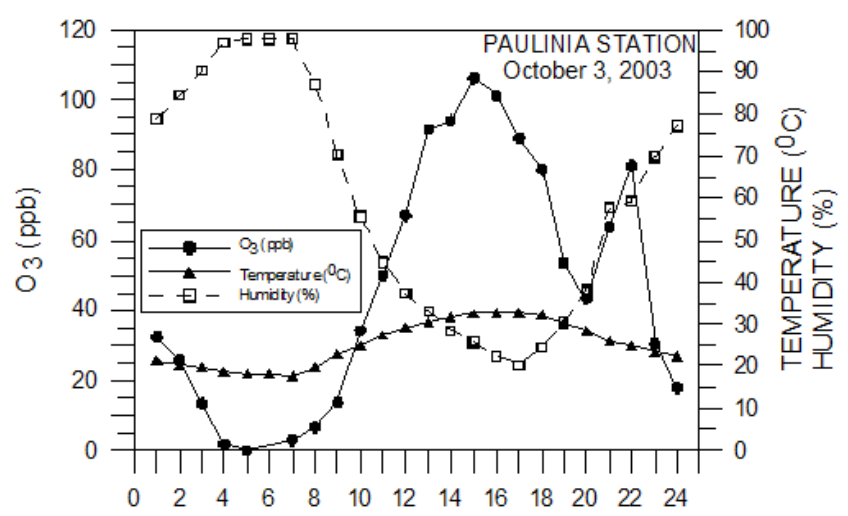

Figura 4 - Hourly ozone concentrations (in ppb), temperature (in 0C) and humidity (in \%) measured by CETESB in Paulinia from October 2 to 3, 2003 (a, b), respectively.

scenery only the local production and transport. All results were grouped according to the division of day in four periods: early morning (Figures 8a and 8b); morning (see Figures 8c and 8d); afternoon (Figures 9a and 9b); evening (Figures 9c and $9 \mathrm{~d}$ ). As expected, during the afternoon, ozone reached the maximum concentrations (100-110 ppb) in both regions: MRSP and MRC (Figure 9a) and the main wind direction was from southeast. An evident effect of transport from MRSP to MRC was observed (see, for example, Figures 9a and 9b). Figure 9a showed the ozone concentrations at 4:00 pm (LT) for scenery one (includes emissions from MRSP and MRC). A plume of high ozone concentrations were observed in both regions: MRC (ozone concentrations around 110-120 ppb) and MRSP (ozone concentrations around 100-110 ppb) what can indicate an interaction between these regions in terms of ozone transport. When the influence of MRSP emissions is removed (see Figure 9b) lower concentrations were observed over MRC (around 70-75 ppb).

The simulations indicated that the presence of ozone peaks at night (around 10:00 pm, LT) in MRC region are due 
(a)

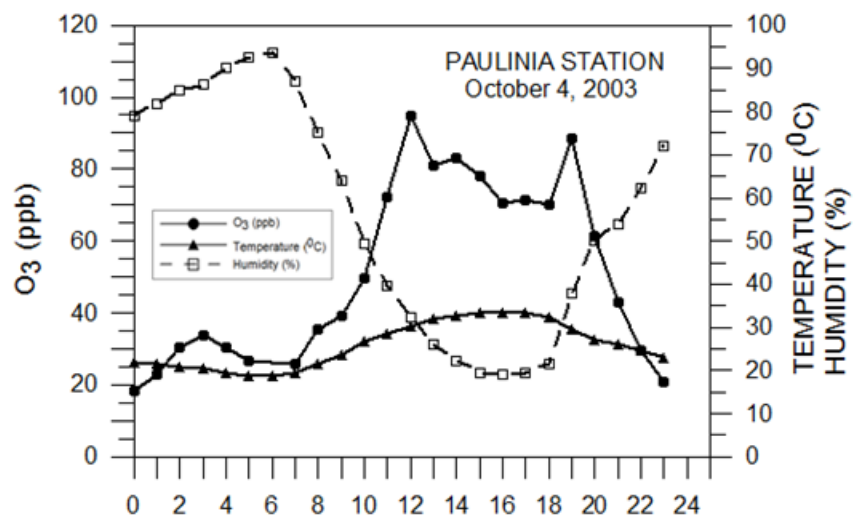

(b)

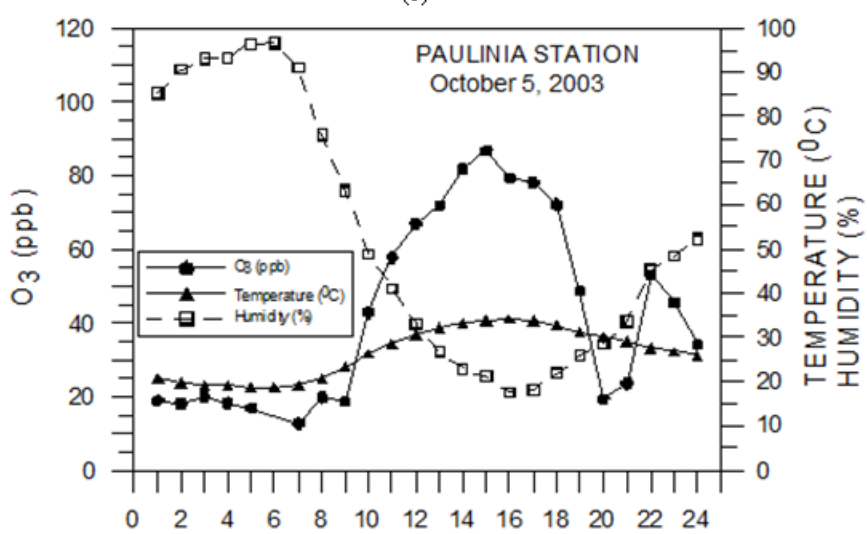

Figura 5 - Hourly ozone concentrations (in ppb), temperature (in 0C) and humidity (in \%) measured by CETESB in Paulinia from October 4 to $5,2003(\mathrm{a}, \mathrm{b})$, respectively.

to transport effects, see Figures $9 \mathrm{c}$ and $9 \mathrm{~d}$. Figure $9 \mathrm{c}$ shows the ozone concentrations at 10:00 pm (LT) for scenery one (includes emissions from MRSP and MRC). A plume of ozone (concentrations around 80-100 ppb) was observed moving toward northeast and other plume come from RMSP reaching $\mathrm{MRC}$ region. When the influence of MRSP emissions is removed lower concentrations were observed over MRC (see Figures $8 b$, $8 \mathrm{~d}, 9 \mathrm{~b}$ and $9 \mathrm{~d}$ ). Theses events of ozone transport at night are responsible for the presence of residual ozone at early morning and morning over MRC region, see Figures $8 \mathrm{a}$ and $8 \mathrm{c}$. As previously observed the conditions responsible for maintaining the transport of ozone and precursors from MRSP to MRC at all the periods of day, for the events of ozone transport at night and the presence of residual ozone at early morning and morning are: (a) the wind direction in the early morning and evening is mostly from S and SE (b) in the evening the wind speed is higher than other periods of day.

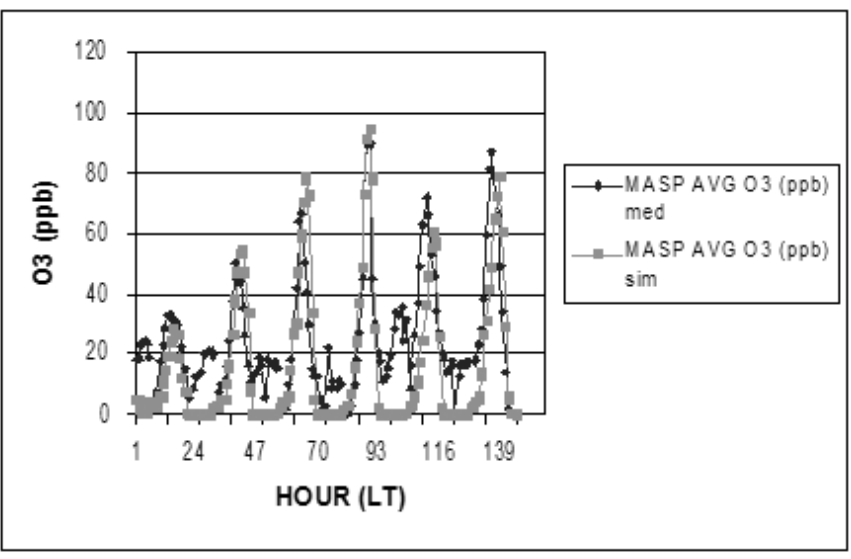

Figura 6 - Comparison between hourly average ozone concentrations measured and simulated (first level of the model - 54m), for MRSP, from September 30, 2003 to October 5, 2003.

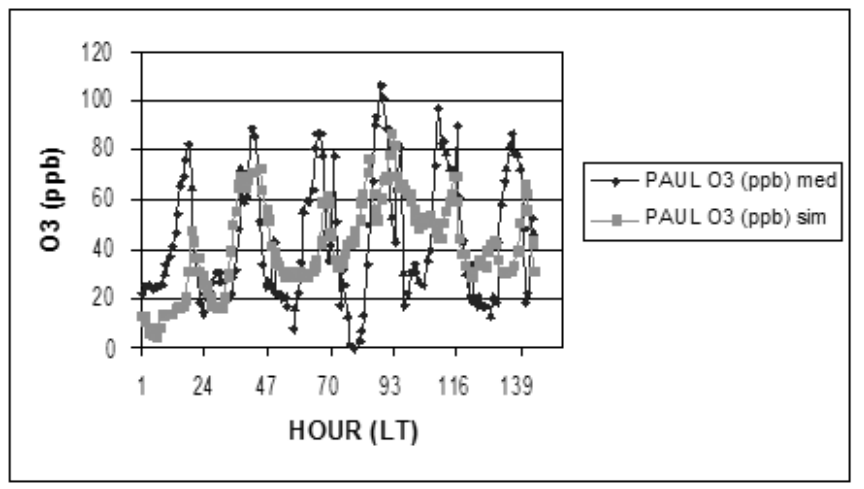

Figura 7 - Comparison between hourly average ozone concentrations measured and simulated (first level of the model - 54m), for Paulinia Station (MRC), from September 30, 2003 to October 5, 2003.

\subsubsection{Vertical ozone profile obtained by simulation}

Figures 10a-10f shows the hourly evolution (local time) of vertical ozone profile in Paulinia city, from September 30, 2003 to October 5, 2003, obtained from simulations considering all emissions (Scenery 1). There is a good agreement between these simulations and ozone hourly evolution observed by measurements. For example on 30 September when a frontal system passed over the region, low surface ozone concentrations were measured (Figure 3a) and the vertical ozone profile shows a clean atmosphere with low ozone concentrations for the five levels of the model. The next day of simulation (Figure 10b) presented higher ozone concentrations (80-130 ppb) along the vertical profile than that simulated in the first day. The maximum concentrations occur in the afternoon (from 3 to 6 $\mathrm{pm}, \mathrm{LT})$. It was not observed residual ozone in early morning due no significant effects of transport from MRSP region to 
MRC. The significant effects of ozone and precursors transport from MRSP were observed on October 2 (Figure 10c); October 3 (Figure 10d) and October, 5 (Figure 10f). During these days it was also observed the presence of residual ozone at night and early morning, suggesting a transport of ozone and precursors from MRSP (mainly wind direction from southeast) and the topography conditions of depression in the MRC that benefits the accumulation of pollutants. The transported ozone remained accumulated in the higher levels of boundary layer being transported to the ground in the following day.

A typical vertical ozone profile during a period with

(a)

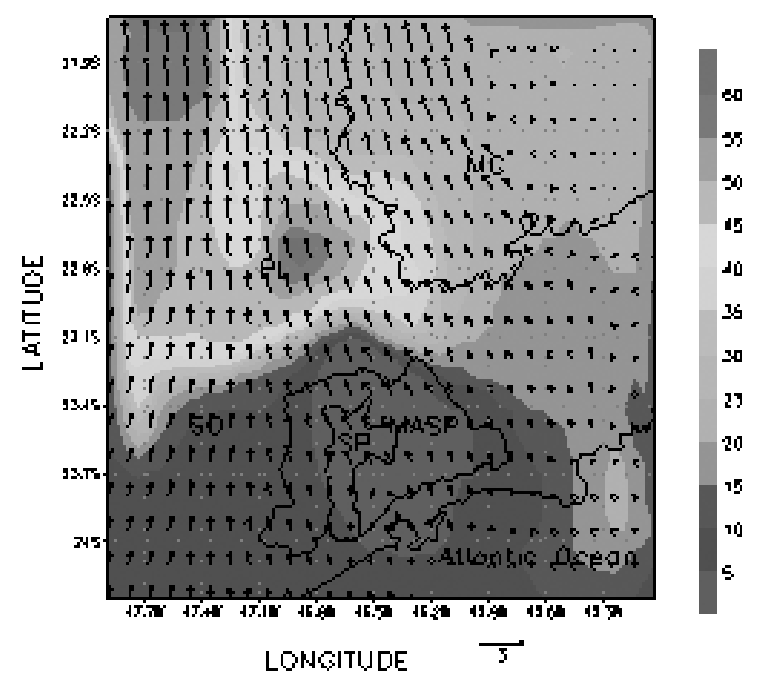

(c)

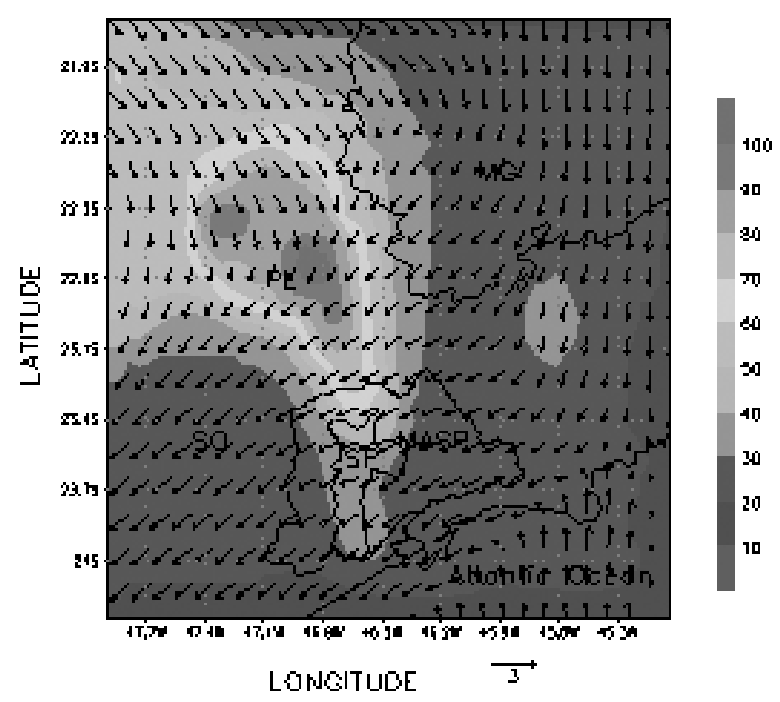

no significant effects of transport is showed in Figure 10e. In this case ozone concentrations reach a maximum during the afternoon (from 1 to $5 \mathrm{pm}, \mathrm{LT}$ ) and a minimum during the night and early morning.

For the opposite case, Figures 11a-11f, when only the influence of MRC emissions is considered in the modeling (Scenery 2), lower ozone concentrations are observed in vertical ozone profile in Paulinia and the majority of the days a typical vertical ozone profile was observed with maximum ozone concentrations during the afternoon (from 1 to $5 \mathrm{pm}, \mathrm{LT}$ ) and a minimum during the night and early morning.

\section{(b)}

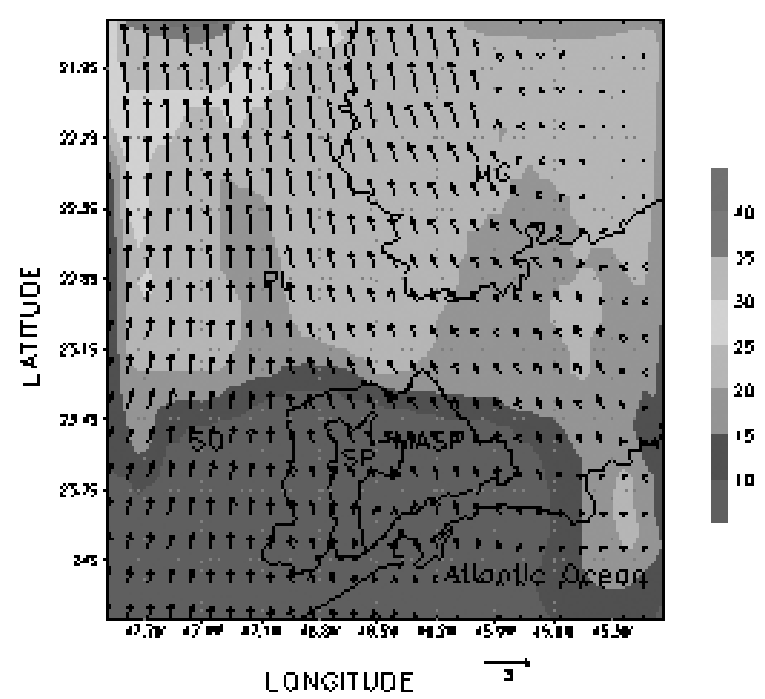

(d)

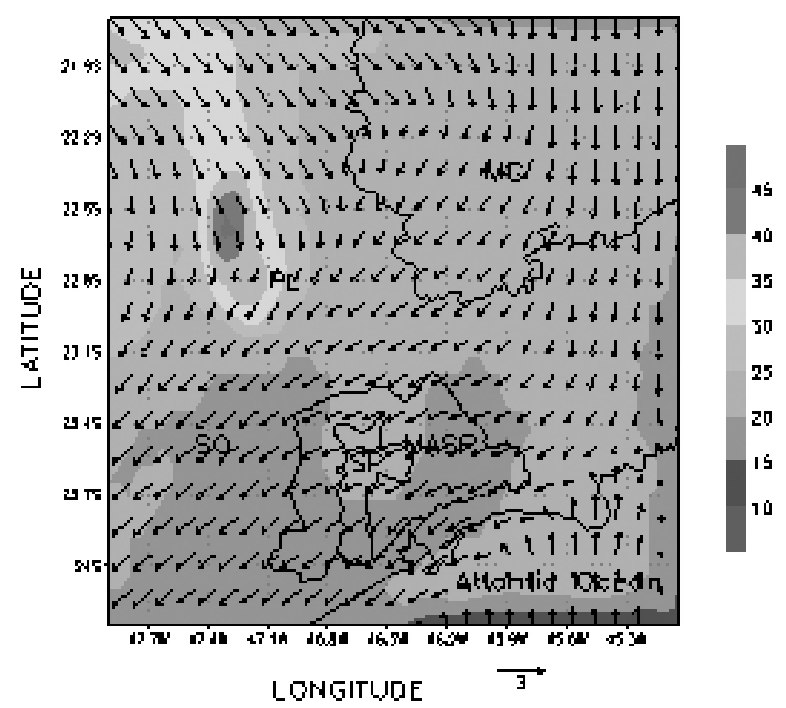

Figura 8 - Ozone concentrations (ppb) and wind fields obtained through photochemical model CIT (first level of the model - 54m) on October 3 , 2003. (a) Scenery 1, 3:00 am (LT); (b) Scenery 2, 3:00 am (LT); (c) Scenery 1, 12:00 pm (LT); (d) Scenery 2, 12:00 pm (LT). PL = Paulinia; SP = São Paulo; $\mathrm{SO}=$ Sorocaba; $\mathrm{MG}=$ Minas Gerais State. The vertical bar shows the ozone concentrations (ppb). 


\section{CONCLUSIONS}

The aim of this work was to determine the interaction in terms of ozone transport between two Metropolitan Regions of São Paulo State: The Metropolitan Region of Campinas (MRC) and Metropolitan Region of São Paulo (MRSP). In order to describe the interaction between both regions, 3-D Eulerian photochemical CIT model was used to simulate the air pollution dynamics for ozone and its transport in the MRC and the MRSP considering the feedback among them. It was a new approach for the study of the ozone transport among these metropolitan regions since previous studies deal with individual

(a)

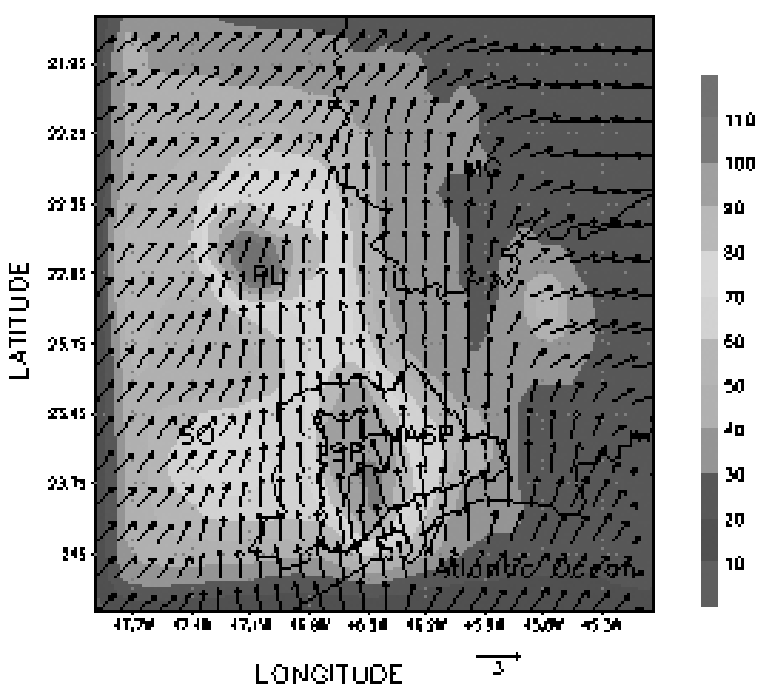

(c)

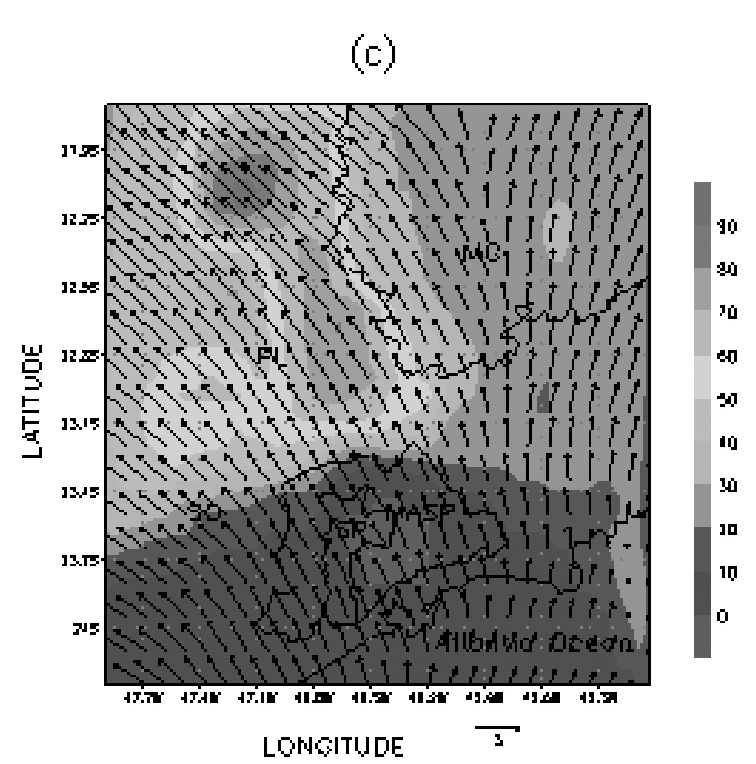

areas considering the contribution of one at another only as boundary conditions. The results obtained during six days of simulation using the photochemical model CIT showed that the ozone concentration in the MRC is associated to local emissions and the transport of ozone and its precursors from the MRSP. The meteorological condition of the region (prevalent wind direction from south and southeast) associated with the topographic characteristic among MRSP and MRC (transition region from plateau to depression, respectively) were favorable to the transport among these metropolitan regions and for the low dispersion of ozone and precursors in the MRC. The results from this preliminary approach are very important considering the fact

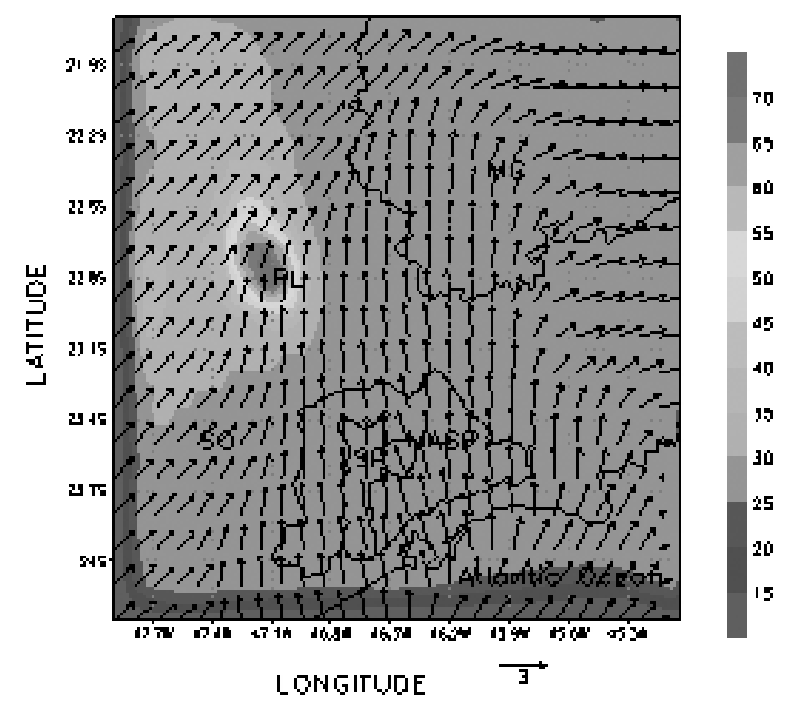

(d)

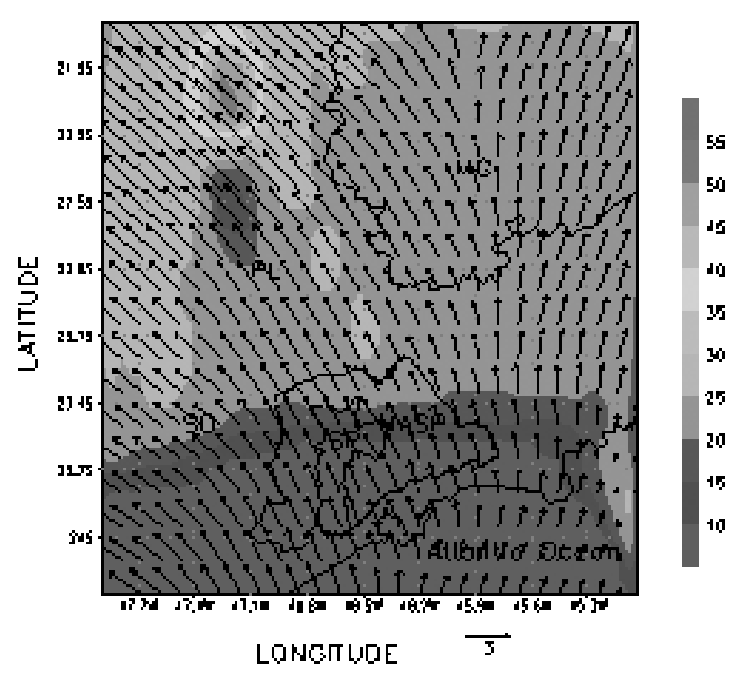

Figura 9 - Ozone concentrations (ppb) and wind fields obtained through photochemical model CIT (first level of the model - 54m) on October 3 , 2003. (a) Scenery 1, 4:00 pm (LT); (b) Scenery 2, 4:00 pm (LT); (c) Scenery 1, 10:00 pm (LT); (d) Scenery 2, 10:00 pm (LT). PL = Paulinia; SP = São Paulo; SO = Sorocaba; $\mathrm{MG}=$ Minas Gerais State. The vertical bar shows the ozone concentrations (ppb). 


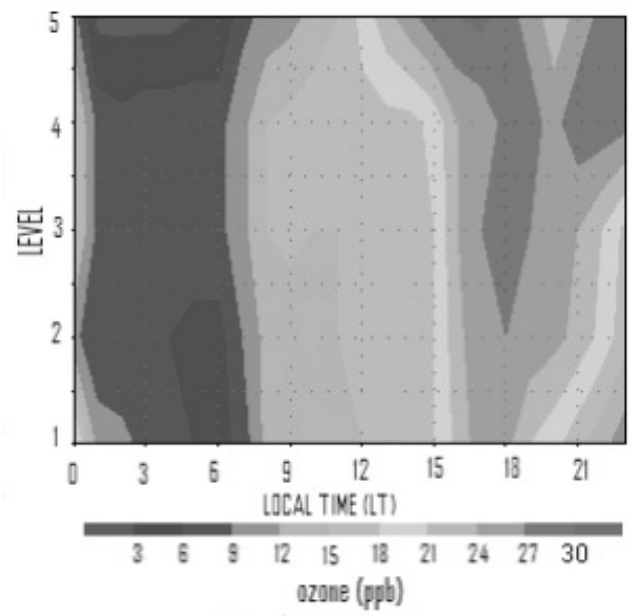

(a)

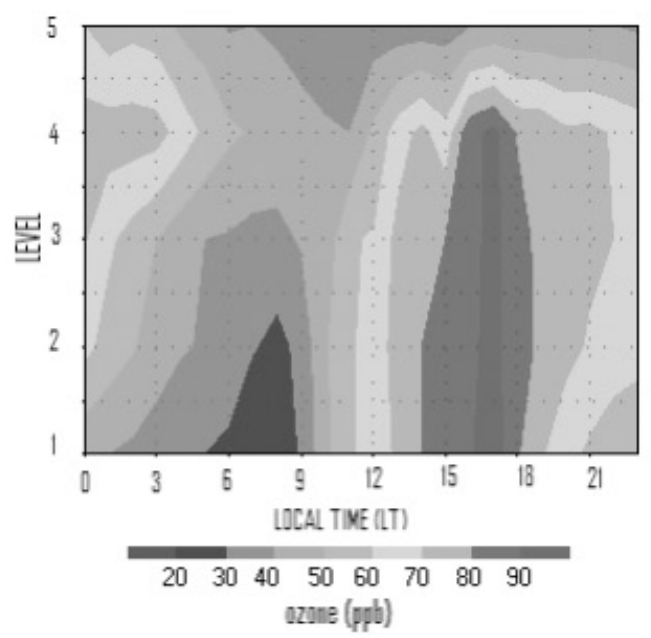

(c)

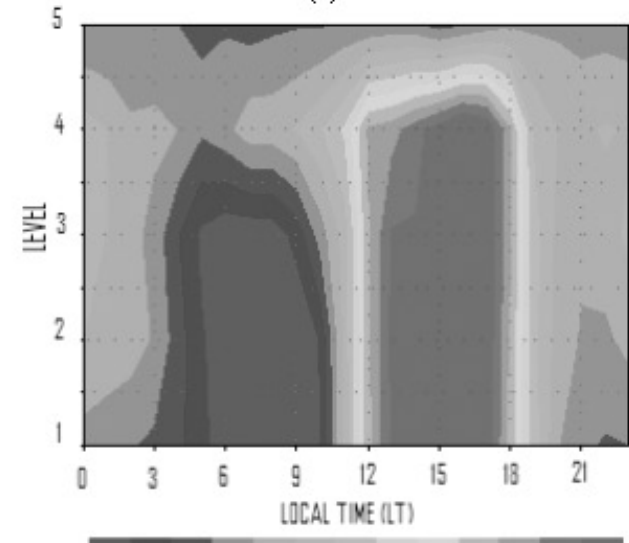

2030405060708090100110120130 ozone (ppb)

(e)

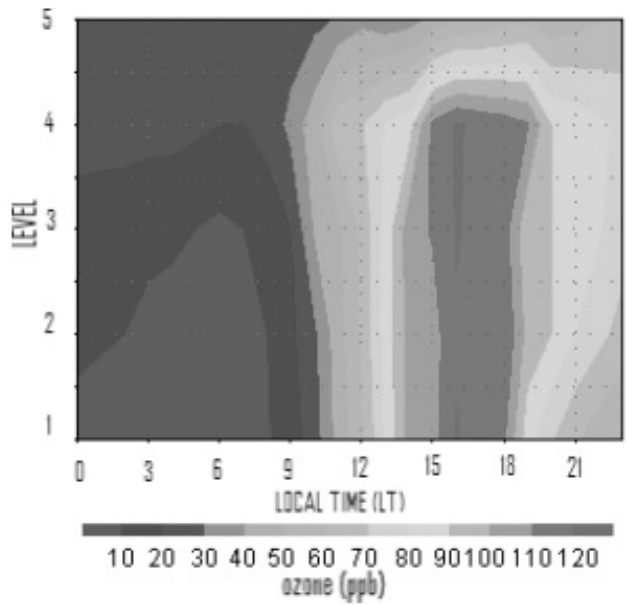

(b)

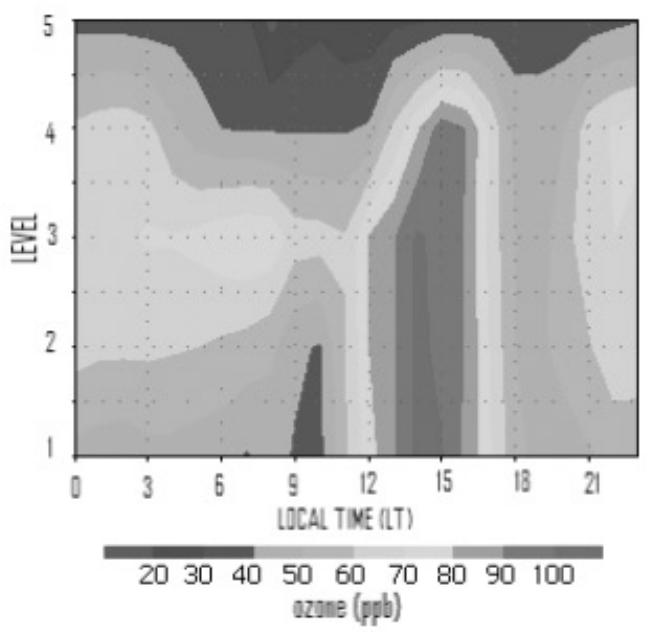

(d)

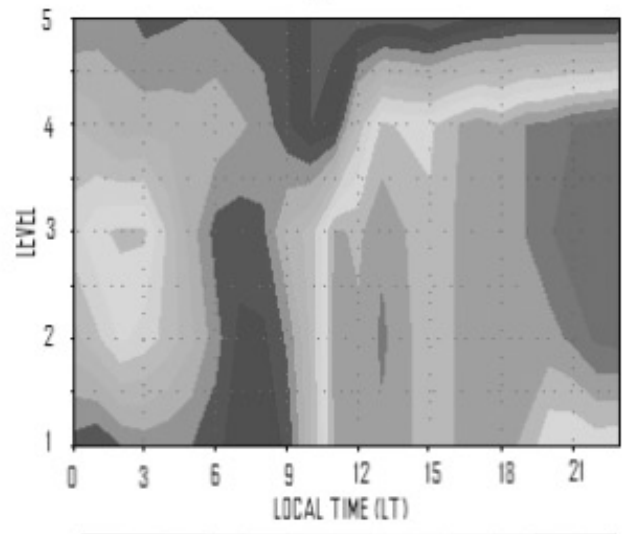

354045505560657075808590 ozone (ppb)

(f)

Figura 10 - Hourly evolution (local time, LT) of ozone concentration in Paulinia city, from September 30, 2003 to October 5, 2003, obtained from simulations as function of vertical level (1-5 levels) of photochemical model considering all emissions (Scenery 1). The bar shows ozone concentrations (ppb). 
(a)

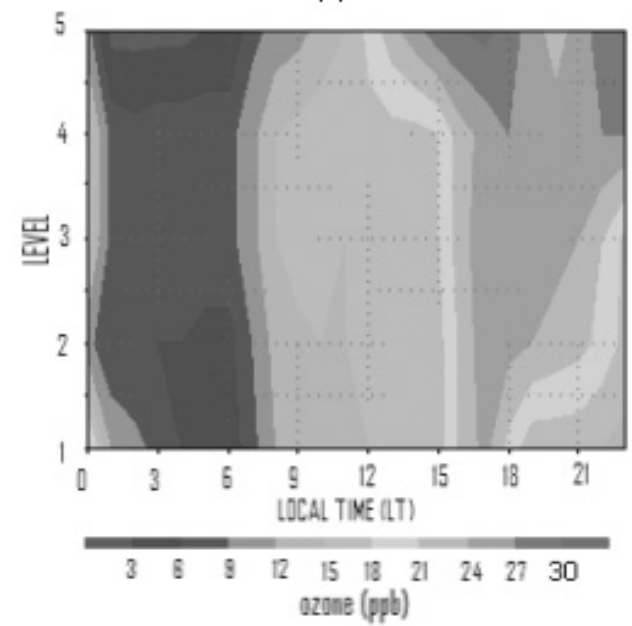

(c)

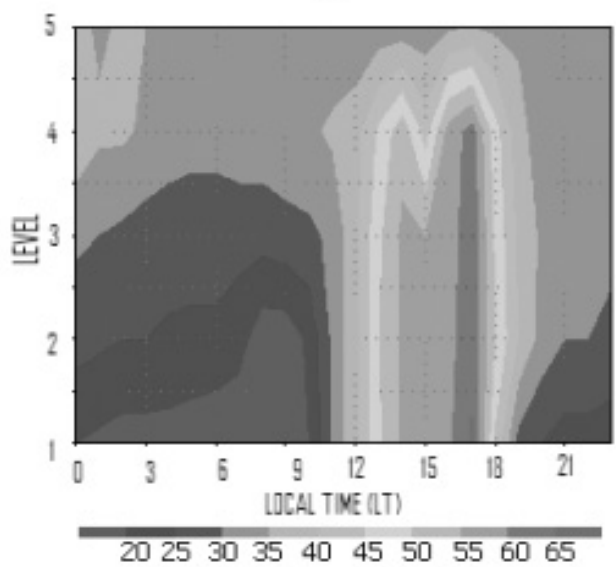

(e)

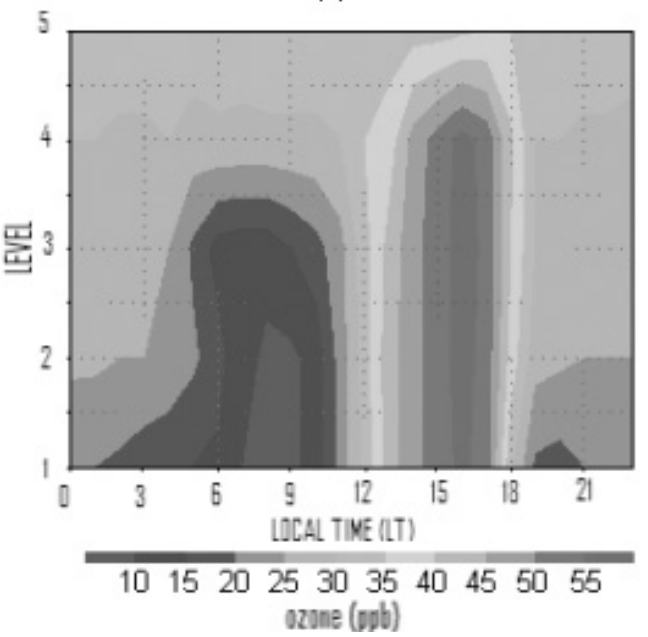

(b)

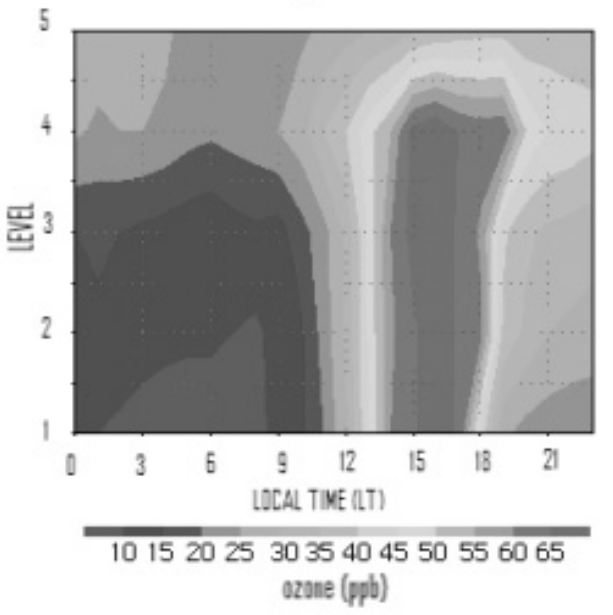

(d)

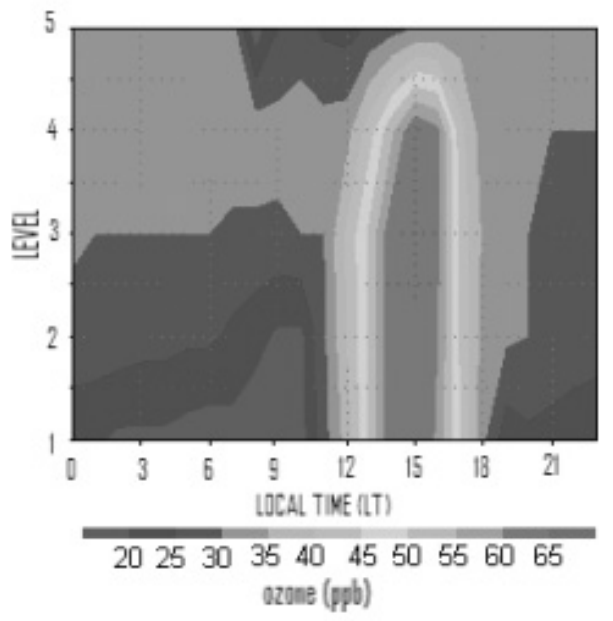

(f)

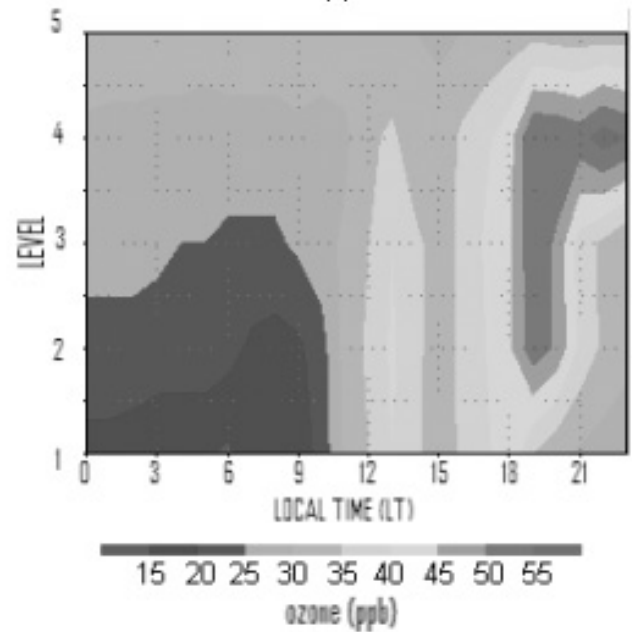

Figura 11 - Hourly evolution (local time) of ozone concentration in Paulinia city, from September 30, 2003 to October 5, 2003, obtained from simulations as function of vertical level (1-5 levels) of photochemical model considering only MRC emissions (Scenery 2). The bar shows ozone concentrations (ppb). 
of this is the first study of the tropospheric ozone pollution for MRC using photochemical model to simulate the air pollution dynamics and to determine the interaction between the most important metropolitan regions in São Paulo State, Brazil (MRSP and MRC). Further studies are necessary including the emissions of stationary sources in the photochemical simulations and also layers above the planetary boundary layer to understand the dynamic of ozone transport in the troposphere.

\section{ACKNOWLEDGEMENTS}

The authors are grateful to the FAPESP (Foundation for Support of Research in the State of São Paulo) for funding this research and the USP (University of Sao Paulo for the logistic support.

\section{REFERENCES}

ALVIM-FERRAZ, M. C. M.; SOUSA, S. I. V.; PEREIRA, M. C.; MARTINS, F. G. Contribution of antrophogenic ozone levels in the Oporto Metropolitan Area, Portugual since $19^{\text {th }}$ century. Atmospheric Environment, 140, 516-524, 2006.

ANDRADE, M. F.; YNOUE, R. Y.; HARLEY, R.; MIGUEL, A. H. Air-quality model simulating photochemical formation of pollutants: the São Paulo Metropolitan Area Brazil. International Journal of Environmental and Pollution, v. 22, n. 4, 460-475, 2004.

CARTER, W. P. L. Implementation of the SAPRC-99 chemical mechanism into the models-3 framework. Report to the United States Environmental Protection Agency. January, 29.<http://pah.cert.ucr.edu/_carter/reactdat.htm>, 2000a.

CARTER, W. P. L. Documentation of the SAPRC-99 chemical mechanism for VOC reactivity assessment. Final Report to California Air Resources Board. Contract No. 92-329, and (in part) 95-308, May 8. <http://pah.cert.ucr.edu/_carter/ reactdat.htm>, 2000b.

CETESB. Relatório de qualidade do ar no Estado de São

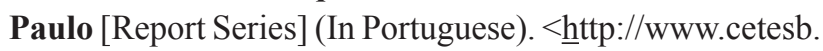
sp.gov.br>, 2003.

CETESB. Avaliação da qualidade do ar no município de Americana, São Paulo [Report Series] (in Portuguese). < http://www.cetesb.sp.gov.br/Ar/relatorios.asp>, 2004.

CPTEC. Centro de Previsão do Tempo e Estudos Climáticos. $<$ http://www.cptec.inpe.br>, 2003.

DETRAN. Departamento Estadual de Trânsito de São Paulo $<$ www.detran.sp.gov.br $>, 2003$.

FREITAS, E. D.; MARTINS, L. D; DIAS, P. L. da S.; ANDRADE, M. F. A simple photochemical module implemented in RAMS for tropospheric ozone concentration forecast in the Metropolitan Area of Sao Paulo, Brazil: Coupling and Validation. Atmospheric Environment, Inglaterra, v. 39, n. 34, p. 6352-6361, 2005.

GOODIN, W. R.; MCRAE, G. J.; SEINFELD, J. H. A comparison of interpolation methods for sparse data: application to wind and concentration fields. Journal Applied Meteorology, v.18, 761-771, 1979.

HARLEY, R.; RUSSEL, A. G.; MCRAE, G. J.; CASS, G. R.; SEINFELD, J. H. Photochemical modeling of the Southern California air quality study. Environmental Science and Technology, v. 27, 378-388, 1993.

LAM, K. S., WANG, T. J., WU, C. L., LI, Y. S. Study on an ozone episode in hot season in Hong Kong and transboundary air pollution over Pearl River delta region of China. Atmospheric Environment, v. 39, n. 11, 19671977, 2005.

LAWRENCE, M. G.; BUTLER, T. M.; STEINKAMP, J.; GURJAR, B. R.; LELIEVELD, J. Regional pollution potentials of megacities and other major population centers. Atmospheric Chemistry Physics, v. 7, n.14, 3969-3987, 2007.

LEI, W.; FOY, B. DE.; ZAVALA, M.; VOLKAMER, R.; MOLINA, L. T. Characterizing ozone production in the Mexico city metropolitan area: a case study using a chemical transport model. Atmospheric Chemistry Physics, v. 7, 1347-1366, 2007.

McRAE, G. J., SEINFELD, J. H. Development of a secondgeneration mathematical model for urban air pollution - I I evaluation of model performance. Atmospheric Environment, v. 17, 501-522, 1983.

McRAE, G. J., SEINFELD, J. H. Development of a secondgeneration mathematical model for urban air pollution - I model formulation. Atmospheric Environment, v. 16, 679-696, 1982.

MAGE, D.; OZOLINS, G.; PETERSON, P.; WEBSTER, A.; ORTHOFER, R.; VANDEWEERD, V.; GWYNNE, M. Urban air pollution in megacities of the world. Atmospheric Environment, v. 30, n. 5, 681-686, 1996.

MARTINS, L.D.;ANDRADE,M.F.; FREITAS,E.D.,PRETTO A., GATTI,L.,A.E.L.,TOMAZE.,GUARDANIM.L.,MARTINS, M. H. R. B., JUNIOR, O. M. A. Emission factors for gaspowered vehicles traveling through road tunnels in São Paulo city, Brazil. Environmental Science and Technology Library, v. 40, 6722 - 6729, 2006a.

MARTINS, L. D.; VASCONCELLOS, P. C.; CARVALHO, L. F.; ANDRADE, M. F. Estimated impact of biogenic hydrocarbon emissions of photochemical oxidant formation in São Paulo during two periods of the winters 1999-2000. Revista Brasileira de Meteorologia, v.21, n.2, 190-200, 2006b. 
MASSAMBANI, O.; ANDRADE, M. F. Seasonal behavior of tropospheric ozone in the São Paulo (Brazil) Metropolitan Area. Atmospheric Environment, v. 28, 3165-3169, 1994.

MOLINA, M. J. AND MOLINA, L. T. Megacities and Atmospheric Pollution. Journal of the Air \& Waste Management Association, v. 54, 644-680, 2004.

RUSSEL, A. G., MCCUE, K. F., CASS, G. R. Mathematical modeling of the formation of nitrogen-containing air pollutants. 1. evaluation of an Eulerian photochemical model. Environmental Science and Technology, v. 22, n. 3, 263-271, 1988.

SÁNCHEZ-CCOYLLO, O. R.; ANDRADE, M. F. The influence of meteorological conditions on the behaviour of pollutants concentrations in São Paulo. Environmental Pollution, v. 116, 257-263, 2002.

SÁNCHEZ-CCOYLLO, O. R.; YNOUE, R. Y.; MARTINS, L. D.; ANDRADE, M. F. Impacts of ozone precursor limitation and meteorological variables on ozone concentrations in São Paulo, Brazil. Atmospheric Environment, v. 40, S552-S562, 2006.
TRESMONDI, A. C. C. L.; TOMAZ, E. Air pollution and the influence of sources on Paulinia (Brazil) and surroundings. International Journal of Environment and Pollution, v. 22, n. 4, 491-506, 2004.

ULKE, A. G., ANDRADE, M. F. Modeling urban air pollution in São Paulo, Brazil: sensitivity of model predicted concentrations to different turbulence parameterizations. Atmospheric Environment, v. 35, 1747-1763, 2001.

VIVANCO, M. G.; ANDRADE, M. F. Validation of the emission inventory in the Sao Paulo Metropolitan Area of Brazil, based on ambient concentrations ratios of $\mathrm{CO}$, NMOG and $\mathrm{NO}_{\mathrm{x}}$ and on a photochemical model. Atmospheric Environment, v. 40, 1189-1198, 2006. 